\title{
UWARUNKOWANIA FUNKCJONOWANIA DRUŻYNY HARCERSKIEJ NA TERENIE GIMNAZJUM SALEZJAŃSKIEGO W SOKOLOWIE PODLASKIM W OKRESIE DRUGIEJ RZECZYPOSPOLITEJ
}

\begin{abstract}
Streszczenie: Praktyczna realizacja harcerskiego systemu wychowawczego w drużynie im. Tadeusza Kościuszki w okresie międzywojennym była różna w poszczególnych okresach. Najpierw praca przebiegała w podniosłym klimacie pierwszych lat niepodległości. Wkrótce nadszedł rok 1920 - wojna z bolszewicką Rosją, kiedy za wierność ideałom i wartościom harcerskim kilku młodych gimnazjalistów zapłaciło najwyższą cenę - swoje życie. Później nastąpił okres systematycznej pracy w drużynie i zastępach, której celem było integralne kształtowanie osobowości harcerzy. Podejmowano próby uatrakcyjnienia tematyki i formy organizacyjnej zajęć harcerskich, aby dostosować je do potrzeb kolejnych roczników młodzieży gimnazjalnej.
\end{abstract}

Słowa kluczowe: harcerstwo; salezjanie; wychowanie; Sokołów Podlaski.

Międzywojenne harcerstwo polskie miało zdecydowanie katolicki charakter. Projektantem krzyża harcerskiego był ks. Kazimierz Lutosławski, a wielokrotnym przewodniczącym Związku Harcerstwa Polskiego (dalej: ZHP) ks. Jan Mauersberger. W drużynach i na obozach kultywowano praktyki religijne. Rozpoczynano Mszą św. wszystkie ważne uroczystości: zjazdy walne, zloty narodowe. W kościołach święcono harcerskie sztandary, a Prawo i Przyrzeczenie Harcerskie zobowiązywały do służby Bogu i Polsce (Fietkiewicz 1985). Zdawał sobie z tego sprawę ordynariusz diecezji podlaskiej bp Henryk Przeździecki, który w 1921 roku powitał z radością projekt przyjmowania przez księży diecezjalnych obowiązków kapelanów harcerstwa polskiego. Z zastrzeżeniem jednak, aby „upatrzony na kapelana kapłan” wcześniej otrzymał „zatwierdzenie Władzy Diecezjalnej” (Protokół 1921, s. 11-12). Początki polskiego skautingu (od ang. scout - „Zwiadowca”) wiążą się ze Lwowem, gdzie funkcjonowały wyższe uczelnie z polskim językiem wykładowym. W środowisku młodzieży akademickiej rodziły się różne ruchy społeczne, polityczne, kulturalne, niepodległościowe, także harcerstwo. Powstanie harcerstwa na terenach polskich od początku było związane z ruchem sokolim. Pierwsze trzy drużyny skautowe powstały w 1911 roku wśród młodzieży tego ruchu. Próbowały one rozszerzyć 
swoje wpływy, sięgając najpierw do młodzieży szkół średnich (Błażejewski 1985). W latach 1918-1939 kadra instruktorska pozostawała pod wpływem politycznym endecji i obozu legionowo-peowiackiego. Najpierw przewage miała w ZHP pierwsza opcja, a później druga.

W istotnej części bibliografii obejmującej dzieje harcerstwa polskiego na Lubelszczyźnie i Podlasiu (Zimmer 1987; 1991; Winiarz 1994; Dąbrowski (red.) 2009; Hardej 2008) ${ }^{1}$ nie ma publikacji (pomijając niżej cytowane, które w większym lub mniejszym zakresie wspominają o drużynie harcerskiej im. T. Kościuszki) ukazującej w pogłębiony sposób funkcjonowanie harcerstwa w Sokołowie Podlaskim, w tym drużyny harcerskiej im. Tadeusza Kościuszki w okresie międzywojennym.

Prezentowany artykuł stanowi próbę spojrzenia na historię drużyny harcerskiej działającej przy Gimnazjum Księży Salezjanów w Sokołowie Podlaskim. Odnotowuje w sposób raczej kronikarski ludzi, fakty i wydarzenia, ale próbuje przedstawić też krótkie wnioski i refleksje mogące posłużyć za podstawę do głębszej już analizy.

\section{Geneza i organizacja gimnazjum sokołowskiego oraz drużyny harcerskiej im. Tadeusza Kościuszki}

Szkołę średnią ogólnokształcącą o nazwie Czteroklasowe Progimnazjum Męskie i Żeńskie w Sokołowie Podlaskim założył w 1915 roku, z pomocą mieszkańców, kapłan diecezji podlaskiej ks. Andrzej Mazurkiewicz (Niewęgłowski 2015). Szkoła cieszyła się dużą popularnością mimo trudności lokalowych, finansowych i kadrowych. Trudności te nasilały się z każdym rokiem w miarę wzrostu liczby uczniów. W 1925 roku Powiatowy Sejmik Sokołowski podjął decyzję o przekazaniu szkoły zgromadzeniu salezjańskiemu. Pierwszym dyrektorem został ks. Jan Bogdański. Po nim funkcję tę pełnił ks. Kazimierz Matuszak, następnie ks. Marcin Massalski, a od 1929 roku ks. Jan Ślósarczyk². Szkoła pod nowym zarządem przyjmowała następujące nazwy: Prywatne Męskie Gimnazjum Księży Salezjanów im. Henryka Sienkiewicza, Gimnazjum Humanistyczne Księży Salezjanów im. H. Sienkiewicza, Prywatne Gimnazjum i Liceum Towarzystwa Salezjańskiego im. H. Sienkiewicza. Salezjanie byli dobrze znani społeczeństwu polskiemu. Od czasu swego przybycia w 1898 roku na ziemie polskie realizowali charyzmat swego założyciela św. Jana Bosko (1815-1888), propagując różne formy działalności wychowawczej i oświatowej. Wcześniej, w latach 1892-1897, ks. Bronisław Markiewicz (1842-1912) jako salezjanin

1 W 1920 roku Sokołów Podlaski podlegał Okręgowi Brzeskiemu ZHP, a od 1934 roku chorągwi lubelskiej (Zimmer 1987).

2 Jan Ślósarczyk (1895-1971) - salezjanin, katecheta, wychowawca kleryków, późniejszy inspektor salezjański. Pod jego kierownictwem gimnazjum sokołowskie uzyskało w 1930 roku prawa gimnazjów państwowych. Dbał nie tylko o zapewnienie warunków bytowych uczniom, lecz także o wyższy poziom nauki i skuteczność wychowania (Woźniak 1992). 
urzeczywistniał idee wychowawcze ks. Bosko w Miejscu Piastowym k. Krosna. Salezjanie organizowali szkoły rzemieślnicze, gimnazja, licea ogólnokształcące, internaty i sierocińce. Przy każdej placówce salezjańskiej funkcjonowała świetlica młodzieżowa, zwana oratorium. Zgodnie z zasadami prewencyjnego systemu wychowawczego oraz innymi środkami wychowawczymi, jak muzyka, sport, przechadzki, teatr, modlitwa, Eucharystia, śpiew, wychowywano młodzież na „dobrych chrześcijan i uczciwych obywateli” (Niewęgłowski 1999, s. 377). W okresie międzywojennym salezjanie utworzyli 31 placówek dydaktyczno-wychowawczych: osiem szkół zawodowych, osiem szkół ogólnokształcących, pięć małych seminariów duchownych i 10 sierocińców (Niewęgłowski 2011).

W gimnazjum sokołowskim obok różnych kół przedmiotowych i organizacji uczniowskich istniały także drużyny harcerskie. Wykorzystywały one idee skautingu w celu przygotowania harcerzy do życia w społeczeństwie. Początki działalności harcerskiej na terenie gimnazjum sięgały pierwszych lat jego istnienia. Władze szkolne i okupacyjne patrzyły nieufnie na rodzące się odważne inicjatywy patriotyczne wśród młodzieży pragnącej w nowy sposób służyć Bogu i Polsce. Uczeń gimnazjum, Wacław Leszczyński, zdołał zwerbować 10 kolegów, którzy dnia 8 marca 1916 roku odbyli pierwszą zbiórkę harcerską (Dziesięciolecie 1935). W tym samym miesiącu na patrona drużyny wybrali Tadeusza Kościuszkę, jako tego, który nigdy nie zwątpił, że Polska odzyska niepodległość. Wkrótce szeregi drużyny powiększyły się do 45 członków. Już w listopadzie 1918 roku mieli oni możliwość praktycznej realizacji ideałów Kościuszki poprzez czynne uczestnictwo w rozbrajaniu Niemców okupujących Sokołów Podlaski. Były też inne przykłady wypełniania obowiązków obywatelskich. W lecie 1920 roku 56 harcerzy wraz ze swoim kapelanem ks. Antonim Święcickim ${ }^{3}$ wzięło udział w wojnie polsko-rosyjskiej (Niewęgłowski 2011). W walkach frontowych poległo siedmiu harcerzy: Józef Włodarczyk (w bitwie pod Wronami 15 sierpnia 1920 roku, w wieku 17 lat), Stefan Golas (pod 13 fortem Grodna dnia 25 września 1920 roku, 16-latek), Wacław Pawlik (uczeń VII kl. gimn., poległ dnia 21 września 1920 roku podczas zdobywania 1 fortu Grodna), Adolf Mastalerczuk, Michał Danielak (poległ w bitwie pod Wronami dnia 15 sierpnia 1920 roku, w wieku 16 lat), Czesław Retke (poległ pod Wronami 15 sierpnia 1920 roku, w wieku 18 lat) i Henryk Leszczyński (Nekrasz 1931), a 19 zostało rannych. Harcerz Geonet Januariusz zmarł w szpitalu z powodu odniesionych ran.

3 Antoni Święcicki (1887-1969) - ksiądz katolicki, doktor prawa kanonicznego, podharcmistrz. W dniu 26 sierpnia 1919 roku otrzymał od bpa Henryka Przeździeckiego nominację na prefekta ośmioklasowego gimnazjum w Sokołowie Podlaskim. Zaczął również udzielać się w pracach drużyny harcerskiej im. T. Kościuszki składającej się z uczniów gimnazjum. W 1920 roku został kapelanem 205 Pułku Piechoty Wojska Polskiego (Gnat-Wieteska 2002; Dąbrowski 2018; AU KUL PK 960). 
W latach następnych podejmowano prace nad ukształtowaniem odpowiednich struktur organizacyjnych. Drużyna została podzielona na zastępy. Ich liczba ulegała zmianom w zależności od liczby członków drużyny w danym roku szkolnym, co ilustruje poniższa tabela.

Tabela 1. Stan liczebny drużyny harcerskiej im. Tadeusza Kościuszki w latach 1929-1938

\begin{tabular}{|l|c|c|c|c|c|c|c|}
\hline $\begin{array}{l}\text { Rok } \\
\text { szkolny }\end{array}$ & $\begin{array}{c}1929 / \\
1930\end{array}$ & $1931 /$ & $1932 /$ & $1933 /$ & $1934 /$ & $1935 /$ & $1937 /$ \\
933 & 1934 & 1935 & 1936 & 1938 \\
\hline $\begin{array}{l}\text { Liczba } \\
\text { członków }\end{array}$ & 30 & 37 & 54 & 40 & 42 & 25 & 30 \\
\hline
\end{tabular}

Źródło: Archiwum Salezjańskie w Sokołowie Podlaskim, Teczka: Sprawozdania. Sprawozdania $z$ działalności drużyny harcerskiej im. T. Kościuszki, bez sygn. (dalej: ASSP, T. Spr.).

Przykładowo w roku szkolnym 1928/1929 było pięć zastępów (Woźniak 1992), 1929/1930 - trzy, 1931/1932 - cztery, 1934/1935 - pięć, 1935/1936 - trzy, 1937/1938 cztery (ASSP, T. Spr). Częstotliwość zbiórek drużyny i poszczególnych zastępów była różna, w zależności od roku szkolnego. Dla przykładu w roku szkolnym 1928/1929 zbiórki drużyny odbywały się dwa razy w miesiącu. Omawiano na nich głównie zagadnienia wspólnej pracy, wybór i dokształcanie zastępowych, prowadzenie zastępów i „zarabianie pieniędzy” (ASSP, T. Spr.; Woźniak 1992, s. 146). Odbywano także próby musztry, uczono się wspólnego śpiewu i opowiadano gawędy harcerskie, które dotyczyły np. wychowania harcerskiego, znaczenia techniki harcerskiej, obowiązkowości, skutków zaniedbania się w kwestii kultury osobistej. Była też okazja do zapoznania się ze wszystkimi członkami drużyny. Istotnym elementem zbiórek były sprawozdania zastępowych ze swej pracy. Przedstawiali oni również trudności, na jakie napotykali. Specjalnie wybrana Rada Drużyny była odpowiedzialna za całokształt działań całej drużyny. Harcerze prowadzili świetlicę, gdzie się spotykali, zarządzali sklepikiem, dzięki któremu zdobywali fundusze i kierowali biblioteczką. Prenumerowali też czasopisma: „Skaut”, „Harcerz”, „Harcmistrz”, „Na Tropie”, „Czyn Młodzieży”, „Młodzież Abstynencka” (ASSP, T. Spr.; Woźniak 1992, s. 147).

Regularne zbiórki zastępów odbywały się każdego tygodnia. Spotykano się na nich, aby m.in. pogłębiać znajomość Prawa i Przyrzeczenia Harcerskiego, które w wersji z 1919 roku zawierało: przyrzeczenie - „Mam szczerą wolę całym życiem pełnić służbę Bogu i Ojczyźnie, nieść chętną pomoc bliźnim, być posłusznym Prawu Harcerskiemu”; zasady prawa - „1. Na słowie harcerza polegaj jak na Zawiszy, 2. Harcerz służy Ojczyźnie i dla niej sumiennie spełnia swoje obowiązki, 3. Harcerz jest pożyteczny i niesie pomoc bliźnim, 4. Harcerz w każdym widzi bliźniego, a za brata uważa każdego innego harcerza, 5. Harcerz postępuje po rycersku, 6. Harcerz 
miłuje przyrodę i stara się ją poznać, 7. Harcerz jest karny i posłuszny rodzicom i wszystkim innym przełożonym, 8. Harcerz jest zawsze pogodny, 9. Harcerz jest oszczędny i ofiarny, 10. Harcerz jest czysty w myśli, mowie i uczynkach, nie pali

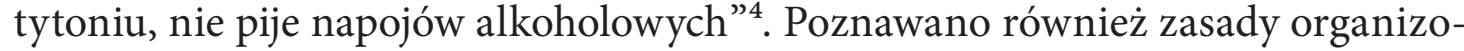
wania obozów, przekazywano wiadomości o sposobach orientowania się w terenie. Zastępy były elementarną częścią drużyny. To od ich aktywności zależały wyniki jej pracy. Liczyły od pięciu do ośmiu osób. W celu zwiększenia aktywności i atrakcyjności pracy zastępów urządzano różne formy współzawodnictwa, m.in. w kwestii realizacji programu drużyny, postępów w nauce, spełniania obowiązków szkolnych i koleżeńskich. W jednym ze sprawozdań czytamy: „Między zastępami konkurs o pierwszy zastęp drużyny. Oprócz rywalizacji sportowej ważniejsza była rywalizacja w nauce: oceny z postępów i zachowania się, karność, punktualność, dobre uczynki, oszczędność oraz ilość przeczytanych książek z lektury harcerskiej” (ASSP, T. Spr.; Woźniak 1992, s. 147).

W roku szkolnym 1929/1930 funkcję drużynowego pełnił uczeń kl. VII Witold Kocowski (od 15 czerwca 1930 roku zastąpił go uczęszczający do kl. V Jan Gabiś). Przybocznym był Tadeusz Mossakowski (kl. V), a zastępowymi byli: Jan Niewęgłowski (kl. VIII), J. Gabiś i T. Mossakowski. Zbiórki wszystkich zastępów odbywały się raz w tygodniu. W zastępach młodszych omawiano tematy związane z harcerstwem: powstanie skautingu, rozwój harcerstwa w Polsce, zasady organizacji ZHP, Prawo Harcerskie. Ponadto chłopcy poznawali pieśni skautów, uczyli się zaplątywać węzły, zdobywali wiedzę o znakach harcerskich i organizowali zawody sprawnościowe o charakterze pokojowym: ping-pong, gry ruchowe usprawniające wzrok, słuch i węch. W zastępach starszych podejmowano kwestie: zawiązania zastępu, ułożenia programu pracy w zastępie i drużynie, analizowano metodykę harców oraz stosunek zastępowego do drużynowego i rodziców chłopców. Zbiórki drużyny odbywały się raz w miesiącu. Poruszano na nich następujące zagadnienia: o znaczeniu przyrzeczenia w życiu harcerza, dlaczego T. Kościuszko jest patronem drużyny, dobry uczynek w życiu harcerza, zasady organizacji obozu, Prawo Harcerskie. Podejmowano też sprawy jakościowego i liczbowego rozwoju drużyny. Harcerze zdobywali stopnie harcerskie. Wśród nich istniały trzy, dostosowane do okresu rozwojowego młodzieży: młodzika (11/12-14 lat), wywiadowcy (12-15 lat), ćwika (człowieka wypróbowanego) (14-17 lat). Od połowy lat 20. ukształtował się na stałe podział na pięć stopni: młodzik, wywiadowca, ćwik, harcerz orli, harcerz Rzeczypospolitej. Dwa ostatnie stopnie zarezerwowano dla młodzieży starszej (od 16 roku życia). Przyrzeczenie harcerskie składano najpierw po odbyciu trzymiesięcznej próby przed przyjęciem do drużyny, a następnie po zaliczeniu pierwszego

4 W 1930 roku zmieniono kolejność pkt. 1 z pkt. 2 oraz wprowadzono słowo „Bóg” do tekstu Prawa, a w 1932 roku zmieniono słowo „Ojczyzna” na „Polska” i usunięto wyrażenie „dla niej” (Hausner, Wierzbicki 2015, s. 319, 324). 
stopnia harcerskiego w czasie kilku-kilkunastomiesięcznej pracy (ASSP, T. Spr.; Czopowicz 2004).

\section{Główne kierunki pracy i specjalizacji harcerskiej (1931-1938)}

Z początkiem lat 30. próbowano prowadzić jak najwięcej zbiórek w terenie. Ułatwiało to organizowanie większej ilości interesujących gier i biegów. Chodziło o to, żeby każda zbiórka harcerska była inna, zaskakiwała harcerzy tematyką i formą organizacyjną. Wpływ na to miała ówczesna sytuacja w harcerstwie. W 1931 roku przewodniczącym ZHP został wieloletni działacz harcerski i człowiek obozu sanacyjnego dr Michał Grażyński. W jego programie pracy wychowawczej zostały wyszczególnione trzy podstawowe idee: „miłości Boga, myśli państwowej, wypływającej z ukochania narodu oraz życia opartego na prawdzie" (Błażejewski 1985, s. 229). Głównym celem działania stało się kształtowanie harcerstwa od wewnątrz poprzez wprowadzanie nowych rozwiązań metodycznych i pożądanych treści pracy wychowawczej. W marcu 1932 roku, w myśl założeń wychowania narodowo-państwowego, wprowadzono nowe programy prób na stopnie organizacyjne. Został położony w nich nacisk na znajomość historii, dorobku kulturalnego i problemów ówczesnej Polski. Harcerstwo stało się szkołą karności w kształtowaniu przyszłego obywatela Rzeczypospolitej. Zaczęły się pojawiać tematy gawęd harcerskich dotyczące pracy dla Polski, odpowiedzialności za jej losy, walki z wadami narodowymi. Najlepszym sprawdzianem całorocznej pracy drużyny był obóz harcerski. Jego zorganizowanie wymagało aktywności, samodzielności i odpowiedzialności wszystkich członków drużyny, gdyż większość rzeczy należało przygotować samemu (Winiarz 2000). Umożliwiało to ukształtowanie w harcerzach cech charakteru eksponowanych w ideale wychowania obywatelsko-państwowego.

Kolejny rok szkolny 1931/1932 przyniósł nowe zmiany w dziejach drużyny im. Kościuszki. We wrześniu 1931 roku Rada Drużyny mianowała drużynowym druha Jerzego Szlezyngiera - wywiadowcę, pierwszym przybocznym druha Jana Gabisia - wywiadowcę i drugim przybocznym druha Henryka Zinowicza - młodzika. Opiekunem drużyny z ramienia Rady Pedagogicznej został dh Stanisław Olędzki - nauczyciel historii i nauki o Polsce współczesnej i komendant miejscowego hufca harcerskiego. Praca w zastępach polegała na wprowadzaniu w życie idei harcerskiej i zapewnieniu druhom należytego wyrobienia harcerskiego (tzn. opanowania sprawności harcerskich). Środkami do osiągnięcia tego celu były: gawędy, odpowiednie książki (np. Harce młodzieży polskiej Mieczysława Schreibera i Eugeniusza Piaseckiego, Lwów 19175), pisma, śpiewy oraz ćwiczenia

5 Licząca 287 stron książka zawierała wzorcowe przykłady 18 gawęd obozowych dla harcerzy na następujące tematy: harce - gry, ćwiczenia, zawody (harcerze w czasie wojny i pokoju, organizacja, stopnie, prawo harcerskie), harcerze w polu (zwiady, sygnały i rozkazy), harcerze w obozie, tropienie, myślistwo harcerza, zdrowie, rycerskość (Pomagaj bliźnim i doskonal samego siebie), 
z terenoznawstwa, sygnalizacji, spostrzegawczości i samarytaństwa (ratownictwa). W listopadzie 1931 roku nastąpiła zmiana kierownictwa. Obowiązki drużynowego przejął dh Jan Gabiś. W marcu 1932 roku odbyły się próby na czwarty stopień. Ważniejsze wydarzenia z życia drużyny: w październiku 1931 roku członkowie drużyny gościli na herbatce dyrektora gimnazjum ks. Jana Ślósarczyka wraz z gronem pedagogicznym, w marcu 1932 roku wizytował drużynę wizytator Okręgu Szkolnego Lubelskiego Stanisław Komar, w kwietniu tego samego roku drużyna obchodziła 15-lecie swego istnienia. Ostatnie wydarzenie zostało uświetnione odświętnym przyrzeczeniem 15 druhów. W uroczystości brały udział cztery drużyny harcerskie z okolicy, przedstawiciele Koła Przyjaciół Harcerzy i młodzież gimnazjum (ASSP T. Spr.).

W roku szkolnym 1932/1933 obowiązki drużynowego pełnił uczeń kl. VII H. Pieliński. Pracowano nad „konsolidacją” wewnętrzną i wyrobieniem harcerskim członków drużyny. Uczęszczali oni do różnych klas gimnazjum: do kl. I - jedna osoba, II - 14 osób, III - 14 osób, IV - 11 osób, V - pięć osób, VI - trzy osoby, VII trzy osoby, VIII - dwie osoby.

Drużyna, jako jedna z organizacji szkolnych, brała udział w urządzaniu różnych uroczystości i obchodów w gimnazjum, np. harcerze samodzielnie przygotowali uroczyste obchody imienin prezydenta Rzeczypospolitej Ignacego Mościckiego.

Zwracano uwagę na wzorowe wypełnianie obowiązków szkolnych. Wszyscy członkowie drużyny otrzymali promocję do klas następnych. Harcerze spotykali się na zbiórkach: cała drużyna - 12 razy, poszczególne zastępy - 50, Rada Drużyny - 10. Zorganizowano jedną pięciogodzinną wycieczkę w okolice Sokołowa Podlaskiego, co umożliwiało „ćwiczenia harcerskie w polu” (ASSP, T. Spr.).

W roku szkolnym 1933/1934 położono szczególny nacisk na karność. Zajmowano się umundurowaniem, zorganizowano kilka wycieczek „w teren”, w czasie których śpiewano pieśni harcerskie i wojskowe oraz ćwiczono rożne gry. Ponadto drużyna brała udział we wszystkich uroczystościach narodowo-państwowych odbywających się w szkole i poza nią. Odczuwano jednak brak wykwalifikowanych zastępowych (ASSP, T. Spr.).

W kolejnym roku szkolnym 1934/1935 jednym z głównym celów pracy drużyny było przygotowanie się do „Jubileuszowego Zjazdu” w Spale. Celem szczegółowym było ukształtowanie cech osobowych: samodyscypliny, wytrwałości i sumiennego spełniania swoich obowiązków. Chodziło o ogólną dzielność i zaradność życiową. Harcerze poznawali teoretycznie sprawności harcerskie na zbiórkach w okresie zimowym. Zdobyte wiadomości dotyczyły nie tylko podstawowych zagadnień z zakresu wychowania obywatelskiego (np. znajomość dziejów walk o niepodległość, kultura narodowa, przyroda ojczysta, instytucje państwowe), lecz także obejmowały sprawy życia codziennego (np. kultura i obycie towarzyskie, higiena

ocalanie życia (ratownictwo, pierwsza pomoc), miłość Ojczyzny (Poznaj Polskę i ucz się jej służć). 
osobista, naprawa bielizny, obsługa apteczki, posługiwanie się mapą, umiejętności radzenia sobie w każdej sytuacji) i utrzymania sprawności fizycznej (różne gry i sporty, pływanie, jazda na rowerze). Harcerze poznawali też m.in. historię i symbole harcerskie, musztrę oraz zasady organizacji obozu harcerskiego. Praktyczne zastosowanie nabytych wiadomości odbywało się w okresie wiosennym podczas wycieczek w tzw. terenie. Drużyna prenumerowała następujące czasopisma: „Na Tropie”, „Czuj Duch” i „Czyn Młodzieży”. Odnowiono własnym kosztem świetlicę harcerską (ASSP T. Spr.; Czopowicz 2004).

Rok szkolny 1935/1936 przyniósł nowe wydarzenia w życiu szkolnej drużyny harcerskiej im. T. Kościuszki. Do grudnia 1935 roku funkcję drużynowego pełnił druh i wychowawca Jerzy Świderski (od 20 stycznia 1936 roku zastąpił go Czesław Rzucidło). W pierwszym półroczu odbywały się próby na stopień młodzika oraz część chłopców przygotowywała się do złożenia przyrzeczenia harcerskiego. Drużyna odbyła w sumie 12 zbiórek. W tym czasie zorganizowano także dwie wycieczki popołudniowe do lasu w Zielonce. Była to dobra okazja do przeprowadzenia zawodów harcerskich i sportowych. W drugim półroczu drużyna odbywała regularne zbiórki w środę każdego tygodnia. Spotkano się w sumie 15 razy. Tematyka podejmowana na zbiórkach dotyczyła: przygotowania technicznego na stopień wywiadowcy, ćwiczeń sprawności fizycznej oraz „urobienia” ideowego. W lutym 1936 roku przyrzeczenie harcerskie złożyło 12 osób w obecności ks. dyrektora J. Ślósarczyka. W maju tego roku natomiast czterech harcerzy ukończyło z wynikiem pozytywnym „bieg harcerski” i otrzymało stopień wywiadowcy. Ponadto cała drużyna została umundurowana. Brała też udział we wszystkich uroczystościach szkolnych. W dniu imienin księdza dyrektora zaplanowano sprawdzian z praktyki „życia harcerskiego” pod namiotami (ASSP T. Spr.).

W roku szkolnym 1937/1938 drużynowym został Tadeusz Pogorzelski. Wyodrębniono osobny zastęp starszoharcerski, w którego skład weszli starsi chłopcy z drużyny. Drużyna odbyła 16 spotkań, w czasie których przeczytano siedem rozkazów - w tym jeden ćwiczebny. Wszystkie cztery zastępy odbyły w sumie 56 zbiórek, z czego 12 przypadało na ćwiczenia terenowe. Rada Drużyny natomiast spotkała się cztery razy. Drużyna brała udział w następujących wydarzeniach: Święto Niepodległości, imieniny prezydenta Rzeczypospolitej Polskiej I. Mościckiego, imieniny marszałka Edwarda Rydza-Śmigłego, święto Konstytucji 3 maja (w czasie uroczystości 10 ochotników złożyło przyrzeczenie harcerskie), imieniny księdza dyrektora, procesja Bożego Ciała, poświęcenie fundamentów pod budowę gimnazjum żeńskiego. Dnia 2 maja 1938 roku harcerze wzięli udział w sztafecie kolarskiej „z listem hołdowniczym” dla prezydenta RP, na trasie Sokołów Podlaski-Siedlce. Na stałe otrzymywano pisma: „Na Tropie”, „W Kręgu Wodzów”, „Polska na Morzu”. Oprócz tego drużyna zajmowała się sprzedażą znaczków na cel budowy Domu Lubelskiego w Górkach Wielkich (ASSP T. Spr.). 


\section{Współpraca z drużyną harcerską im. Hetmana S. Żółkiewskiego}

W sprawozdaniach za rok szkolny 1935/1936, dotyczących działalności organizacji szkolnych na terenie gimnazjum, znalazło się sprawozdanie z pracy II gimnazjalnej drużyny harcerskiej im. Hetmana S. Żółkiewskiego. Już w październiku 1935 roku wizytował ją komendant Chorągwi Harcerzy harcmistrz RP Dymitr Senatorski. Drużyna liczyła 28 członków i była podzielona na trzy zastępy. We wspomnianym roku szkolnym odbyła 14 zbiórek ogólnych. Zastępy odbyły łącznie 48 zbiórek. Praca na zbiórkach, np. z nowymi członkami drużyny, była podzielona na etapy. W pierwszym etapie zaznajamiano przybyłych chłopców z zasadami i organizacją ZHP, a jednocześnie przerabiano z nimi program na stopień młodzika. W drugim etapie 13 chłopców zaliczyło próby na wspomniany stopień. W dniu 3 maja 1936 roku złożyli oni przyrzeczenie harcerskie. Na uroczystości złożenia przyrzeczenia obecni byli harcerze z drużyny im. T. Kościuszki wraz z opiekunem S. Olędzkim oraz komendant hufca męskiego Wincenty Dziurzyński (ASSP T. Spr.).

Obie drużyny współdziałały ze sobą w przygotowywaniu uroczystości szkolnych oraz pomagały innym organizacjom szkolnym w urządzaniu uroczystych obchodów danego święta czy wydarzenia ${ }^{6}$. Harcerze mobilizowali pozostałych uczniów gimnazjum do lepszego wypełniania obowiązków szkolnych oraz zajmowania właściwej postawy etyczno-moralnej i obywatelskiej wobec zjawisk życia koleżeńskiego, szkolnego, społeczności lokalnej czy narodowej. Brali także udział w imprezach, które odbywały się poza terenem szkoły.

W zakończeniu należałoby wymienić ważniejsze akcje z historii drużyny im. T. Kościuszki w latach 1921-1936: w 1921 roku -udział w kweście na rzecz Śląska (komendant Okręgu Brzeskiego ks. Fabian Szczerbicki w rozkazie L. 12 z dn. 12/V-1922 r. uznał harcerzy z drużyny im. T. Kościuszki za wzór do naśladowania), w 1924/1925 - udział w uroczystościach odsłonięcia pomnika komendanta powstania 1863 roku na Podlasiu ks. Stanisława Brzóski, w 1925/1926 - współpraca w organizowaniu obchodów 10-lecia harcerstwa w Sokołowie Podlaskim, w 1928 roku - udział w uroczystości odsłonięcia pamiątkowej tablicy uczniów-harcerzy poległych w 1920 roku, która została wmurowana w jedną ze ścian gimnazjum (podczas uroczystości obecny był bp Henryk Przeździecki), w 1929 roku - uczestnictwo w II Zlocie Narodowym Harcerzy w Poznaniu (tam drużyna zajęła jedno z pierwszych miejsc w konkursie stawiania namiotów, śpiewie i siatkówce), w 1934/1935 - Zlot ZHP w Spale, w 1935/1936 - przygotowanie uroczystości 2o-lecia drużyny (Dziesięciolecie 1935).

6 Ze sprawozdań dyrekcji z życia szkoły salezjańskiej w latach 1928-1939 (bez uwzględnienia uroczystości powtarzających się w kolejnych sprawozdaniach) wynika, że odbyło się ponad 80 uroczystości i imprez gimnazjalnych (Woźniak 1992). 


\section{Zakończenie}

W działalności drużyny harcerskiej im. Tadeusza Kościuszki w okresie międzywojennym można wyodrębnić trzy etapy. Pierwszy rozpoczął się od momentu jej założenia i trwał do 1925 roku, kiedy placówkę szkolną przejęli salezjanie. Charakteryzował się on przede wszystkim tym, że wzrosła liczba gimnazjalistów zainteresowanych polskim ruchem skautowym. Jego istotą było wychowanie chłopców na światłych obywateli, gotowych do pracy i poświęceń dla kraju. Głównym celem wychowania i samowychowania było wykorzenienie wad narodowych, wdrożenie do obowiązkowości i pracowitości, ukształtowanie silnej woli i nieugiętego charakteru, przygotowanie do walki o niepodległość Polski z bronią w ręku (skauting oraz niepodległość). Najwyższymi wartościami były: Bóg i Ojczyzna, pomoc bliźniemu i posłuszeństwo Prawu Harcerskiemu. Ujawniło się to w 1918 roku, a szczególnie w 1920 roku, gdy kilku chłopców oddało życie podczas wojny z bolszewicką Rosją. Opiekę duchową i instruktorską nad drużyną sprawował wówczas ks. Antoni Święcicki.

Drugi etap rozpoczął się w latach 20. i trwał do początku lat 30. Starano się wówczas dokładnie poznać Prawo i Przyrzeczenie Harcerskie oraz próbowano wcielać je w życie. Dbano o integralne wychowanie harcerskie rozwijające intelekt, wolę, uczucia i sprawność fizyczną.

W trzecim okresie, zgodnie z nowymi wytycznymi ZHP, drużyna im. T. Kościuszki usiłowała odbywać więcej zbiórek w terenie. W tematyce gawęd harcerskich większy nacisk położono na sprawy ówczesnej Polski i pracy na rzecz jej rozwoju. Harcerze pozostawali pod duchową i merytoryczną opieką księży dyrektorów salezjańskich, najdłużej ks. dyrektora Jana Ślósarczyka. Często wizytował on drużynę, zarażał salezjańskim optymizmem i radością życia, motywował do pracy, tzn. angażował do organizowania lub do pomocy w przygotowywaniu uroczystości i imprez gimnazjalnych i nie tylko. Było to zgodne z pedagogią św. Jana Bosko, według której przełożeni biorą czynny udział w zajęciach swoich podopiecznych.

Do najważniejszych przejawów działalności formacyjnej i wychowawczej drużyny im. T. Kościuszki w latach 1918-1939 należy zaliczyć: wdrażanie do patriotyzmu przez spełnianie obowiązków obywatelskich (w tym względzie członkowie drużyny byli wzorem do naśladowania), uczenie musztry, śpiewu, spełniania obowiązków uczniowskich; prowadzenie gawęd harcerskich na temat zagadnień wychowania harcerskiego, nauka techniki harcerskiej, obowiązkowości i kultury osobistej, położenie nacisku na poznanie i wypełnianie Przyrzeczenia i Prawa Harcerskiego oraz na zdobywanie stopni harcerskich: młodzika, wywiadowcy, ćwika, harcerza orlego. Ponadto organizowano konkursy pomiędzy zastępami. Oprócz rywalizacji sportowej istotna była rywalizacja w nauce: oceny z postępów i zachowania się, karność, punktualność, dobre uczynki, oszczędność, liczba przeczytanych książek o tematyce harcerskiej. Duże znaczenie przywiązywano do obozów, wycieczek i gier 
sportowych w terenie (na II Zlocie Narodowym Harcerzy drużyna uzyskała czołowe miejsce w konkursie stawiania namiotów, śpiewie i siatkówce). Koncentrowano się na poznawaniu historii scautingu i symboli harcerskich oraz zasad organizacji obozu harcerskiego, na kształtowaniu samodyscypliny, wytrwałości i sumienności. Realizowano wychowanie obywatelskie poprzez poznawanie dziejów walk o niepodległość Polski, współczesnych problemów ojczyzny, kultury narodowej, przyrody i organizacji instytucji państwowych. Dotykano spraw dzielności, zaradności życiowej, a także zagadnień z życia codziennego, obycia towarzyskiego, zachowania zasad higieny i utrzymania sprawności fizycznej.

\section{Bibliografia}

Archiwum Uniwersyteckie KUL (AU KUL). Teczka: Ks. Święcicki Antoni 1922-1926 [1928], sygn. PK 960.

Archiwum Salezjańskie w Sokołowie Podlaskim (ASSP). Teczka: Sprawozdania 1926-1938. Sprawozdania z działalności drużyny im. Tadeusza Kościuszki $w$ Sokołowie Podlaskim, bez sygn.

Błażejewski W. (1985). Z dziejów harcerstwa polskiego 1910-1939. Warszawa: Młodzieżowa Agencja Wydawnicza.

Czopowicz S. (2004). Bogu, Polsce, bliźnim. Obraz Harcerstwa Rzeczypospolitej Niepodległej: spuścizna ideowa i wychowawcza. Warszawa: Agencja Wydawnicza i Reklamowa AKCES.

Dąbrowski S.J. (2018). Księża i zakonnicy w stuleciu Związku Harcerstwa Polskiego na Lubelszczyźnie. Lublin: Wydawca Ks. Robert Śliż.

Fietkiewicz O. (1985). Przedmowa, W: Błażejewski W., Z dziejów harcerstwa polskiego. Warszawa: Młodzieżowa Agencja Wydawnicza.

Gnat-Wieteska Z. (2002). Ksiądz Szambelan dr Antoni Święcicki. Garwolin: Wydawca Głos Garwolina.

Harcerze Lubelszczyzny w wojnie polsko-bolszewickiej 1919-1920. Materiały do dziejów. Dąbrowski S. J. (red.). (2009). Lublin: Wydawnictwo Tylda.

Hardej B. (2008). Z dziejów sokołowskiego harcerstwa. W: „Pieśń ujdzie cało...”. Historia i legendy ziemi sokołowskiej. Kwiek W. (red.). Sokołów Podlaski: Miejska Biblioteka Publiczna w Sokołowie Podlaskim.

Nekrasz W. (1931). Harcerze w bojach. Przyczynek do udziału młodzieży polskiej w walkach o niepodległość ojczyzny w latach 1914-1921. Warszawa: Główna Księgarnia Wojskowa.

Niewęgłowski J. (1999). Salezjańskie Liceum im. Henryka Sienkiewicza w Sokołowie Podlaskim - historia i wychowanie, „Seminare”, t. 15, s. 377-388.

Niewęgłowski J. (2011). Wychowawczo-społeczna działalność salezjanów w Polsce w latach 1898-1989. Warszawa: Towarzystwo Naukowe Franciszka Salezego.

Niewęgłowski J. (2015). Towarzystwo Salezjańskie wobec wyzwań edukacyjnych w latach 1918-1939. „Seminare”, t. 36, nr 1, s. 151-162. 
Winiarz A. (2000). Funkcjonowanie harcerskiego systemu wychowawczego w okresie II Rzeczypospolitej. Ciagłość czy zmiana? W: Katolicka a liberalna myśl wychowawcza w Polsce w okresie międzywojennym. Walewander E. (red.). Lublin: Redakcja Wydawnictw KUL.

Winiarz A. (1994). Związek Harcerstwa Polskiego na Lubelszczyźnie 1918-1939. Lublin: Wydawnictwo UMCS.

Woźniak R. (1992). Prywatne Męskie Gimnazjum i Liceum Księży Salezjanów im. Henryka Sienkiewicza w Sokołowie Podlaskim (1915) 1925-1948. Lublin (mps). Archiwum Uniwersyteckie KUL, sygn. T. m. 4989.

Zimmer B. (1987). Harcerstwo Lubelszczyzny. Lublin: Lubelska Komenda Chorągwi ZHP. Zimmer B. (1991). Harcerskie środowiska Lubelszczyzny. Zarys historyczny. Lublin: Stowarzyszenie Harcerstwa Katolickiego „Zawisza” w Lublinie.

Protokót VIII konferencji X. X. Dziekanów, odbytej $w$ dniu 16 listopada $1921 r$. $w$ Siedlcach, pod przewodnictwem Ks. Biskupa Ordynariusza. „Wiadomości Diecezjalne Podlaskie", nr 11-12, s. 154-160.

Dziesięciolecie Zakładu i dwudziestolecie Gimnazjum Ks. Salezjanów im. Henryka Sienkiewicza w Sokołowie Podlaskim: 1915-1925-1935. Sokołów Podlaski [b.d.w]. Aneks. W: Hausner W., Wierzbicki M., Sto lat harcerstwa. Warszawa: Instytut Pamięci Narodowej.

\title{
CONDITIONS OF FUNCTIONING OF A SCOUT GROUP IN THE SALESIAN HIGH SCHOOL IN SOKOŁÓW PODLASKI DURING THE SECOND POLISH REPUBLIC
}

\begin{abstract}
Practical implementation of the scouting educational system in the Tadeusz Kościuszko team in the interwar period was different in different periods. First, the work was carried out in the elevated spirit of the first years of independence. Soon came a war of 1920 with Bolshevik Russia, when a few young junior high school students gave their lives for loyalty to the ideals and scout values. Later, there was a period of systematic work in the team and patrols, whose goal was personal integrity of the scouts. Attempts have been made to enhance the subject matter and organizational form of the scouting training to adapt them to the needs of subsequent years of junior high school youth.
\end{abstract}

Keywords: scouting; Salesians; education; Sokołów Podlaski.

Marek Jurczyszyn - doktor nauk humanistycznych w zakresie pedagogiki, absolwent UMCS i KUL, nauczyciel. W badaniach naukowych z historii wychowania XIX i XX wieku interesuje się szczególnie oświatą wsi z Mieczysławem Brzezińskim na czele i dziejami pedagogii katolickiej diecezji siedleckiej w czasie sprawowania biskupstwa przez bpa Henryka Przeździeckiego w II Rzeczypospolitej. Bierze udział w pracach stowarzyszeń naukowych: Towarzystwa Naukowego Franciszka Salezego, Towarzystwa Naukowego KUL. Adres e-mailowy: marek-jurczyszyn@wp.pl. 